\title{
Are businessmen a benefit to public policy? And if so, what specifically can they offer?
}

\author{
Jan Urban ${ }^{1, *}$ \\ ${ }^{1}$ Institute of Technology and Business in České Budějovice, Faculty of Corporate Strategy, Okružní \\ 517/10, 37001 České Budějovice, Czech Republic
}

\begin{abstract}
.
Research background: The closer interaction between business and government has, on a global basis, drawn attention to the "revolving doors" issue, i.e. the movement of persons between high posts in the public and private sectors.

Purpose of the article: The main research question of this study covers the issue whether successful businessmen do or do not have better prospects for more effective political governance and economic policy making than career politicians or political professionals, and/or if politics and business require, for achieving their goals, similar or substantially different personal requirements.

Methods: The survey was based on multidisciplinary qualitative comparative approach and literature research, covering historical, economics, management, and psychological views. This method corresponds the complex nature of the topics surveyed.

Findings \& Value added: The findings arrived to the conclusion that even a person successful in business may not necessarily have the expertise for effective public administration as well as sound public policy decisions. It showed that the opposite idea, coming often from businessmen circles themselves, fails to take into consideration that government, due to several reasons, cannot be operated like a business and many characteristics of successful businessmen do not fit well to high political posts, due both to their management style and "professional blindness" in terms of their approach to economic policy, e.g. international trade. Even though many management methods of successful companies can and should be taken over by the state/public administration, this goal can be achieved without the direct personal involvement of professional businessmen.
\end{abstract}

Keywords: Suitability of politicians for high political posts; limits of personal and managerial style of entrepreneurs in politics; important personal traits of successful politicians; economic blindness of entrepreneurs in politics.

JEL Classification: L26; M12; D72; D22.

* Corresponding author: 21537@mail.vstecb.cz 


\section{Introduction}

Though many businessmen, seeking to enter top politics worldwide, offer their voters business or managerial experience [1], referring to their success in business and claiming that they will take care, with similar success, of the management and administration of public affairs, the academic study of the successes/failures of businessmen in making both economic and public policy decisions is relatively rare [1].

Therefore, the answer to the question whether businessmen can be in their claims, made to their potential voters, trusted or not is not simple [2]. It is thus not surprising that while many of their supporters obviously hear to them, others fear that for many businessmen politics is just a "continuation of business by other means".

\subsection{The revolving door concept}

The term of "revolving doors" refers to "the movement of individuals between the public and private sectors" $[1,2]$. Although such a movement may bring the public administration certain advantages [3], mainly in the form of the introduction of effective management practices applied in the private sector, to public administration, it also poses significant risks and problems [4, 5]. The revolving door can, therefore, have both positive and negative consequences and in a lot of cases it is up to the regulation of this phenomenon to minimize the risks $[2,6]$.

\subsection{Conflicts of interests}

In forefront of the negative phenomena associated with the revolving door issue lie the conflicts of interest and/or corruption [7, 8], developing due to closer ties between government and individual businesses $[9,10]$.

While public officials with a commercial background may use their position for the benefit of the companies in which they still hold substantial stakes, former members of the government who had moved to the private sector can, on the other hand, help their companies gain unfair advantages through their remaining alliances in government $[11,12]$.

Also, many of the wealthy businessmen are rather "rent-seekers," persons who seek wealth through political favours and who lobby for special privileges that will help their businesses with no regard to whether it is good or bad for the worker, consumer and/or the economy as a whole $[9,11,13]$.

\subsection{Businessmen economic policy fallacies}

Leaving aside the problem of conflicts of interest, which can usually be legally resolved [14], an equally important question concerns the fact to what extent politics and business require similar or, on the contrary, substantially different broader personal requirements. In other words, whether the skills, experience and other personal/personality prerequisites needed in business also work in politics or public administration.

An important part of this problem, associated with businesspeople economic policy engagement, is reflected in the belief that as persons who have been successful in business they must have the knowledge to make wise decisions regarding economic policy $[2,4,5$, 6]. As we have tried to show in a previous publication [15], there is, however, a significant difference between corporate governance and the administration of a national economy.

Entrepreneurial skills, undoubtedly valuable, do not guarantee any real understanding of economic policy making. Often, it is quite on the contrary. The reason is that economics 
and business are not the same thing and what is good for (a particular) business may not be necessarily good for a particular economy as a whole (and vice versa), as the "Fallacy of Composition" claims [15].

As Ludwig von Mises in his Theory of Money and Credit [15] argued: "that there are no grounds for ascribing authoritative significance to the opinions of business men; for economics, these opinions are nothing more than material, to be worked upon and evaluated. When the business man tries to explain anything he becomes as much a "theorist" as anybody else; there is no reason for giving a preference to the theories of the practical merchant or farmer" [15].

Thus, while it is possible that a policy which is good for a given business is beneficial for the economy as a whole, it is equally plausible that a policy that favours a specific business harms the overall economy. Thus, running the economy like a business - or through a business perspective - can quite likely be damaging.

Illustrating this on a simple example, a businessman fighting for a certain percentage of the market share (in a free market environment) will usually drive quality up and prices down. In the international trade, however, a businessmen-turned-politicians, viewing the national economy in the same manner and thinking like businessmen, will follow the aim is to "fight" other national economies which can be for "his" economy detrimental.

This fallacious thinking (so called "zero-sum fallacy") which businessmen tend to follow due to the reason mentioned above - the belief that economy can or even should be run like a business. The truth, however, is that while the growth of a competing company occurs at the expense of the original entrepreneur, the same does not apply to the growth of another country: unlike market share, economic growth is potentially infinite.

Therefore, if a foreign country grows, our national economy is not necessarily worse off; in fact, it is likely to be better off because of the international trade which means that if the foreign economy produces more, consumers in our country can obtain goods more cheaply. This is what economics calls a "win-win" situation.

Thus, to compete with other countries, and "protect" national industries, businessmenturned-politicians often erect trade barriers, hurting other countries. These policies, however, hurt all other countries involved, including their own one.

A similar example covers minimum wages. Though beneficial to a great part of workers, they often put smaller competitors out of business. Similarly, licensing laws and regulations etc. are commonly employed by rent-seeking enterprises at the expense of others. The business-turned-politicians are, however, usually the kind of who steer economic policy in this way.

\section{Method}

This mainly qualitative methodology of this article corresponds the nature of the topics surveyed. It fulfils the methodical requirements raised by, for example, by Denzin and Lincoln [16], who state, that this type of method is best corresponds studies which focus on problems with more complex hypotheses and unavailability of more extensive homogenous research samples. Furthermore, this type of a study is generally an approach in social and/or socioeconomic disciplines [17]. 


\subsection{A look into history}

It would seem that the question whether successful businessmen have better prospects for public governance than professional politicians should be decided by history.

The problem, however, is that the only country where the success of its leading policies can be compared in the long run is the United States. Not only because their political system has been stable enough for a long time, but also because the success of their presidents has traditionally been compared in detail, decades later.

Even though the American experience cannot be completely generalized, a look at the American experience over the last 150 years or so $[18,3]$ shows that these comparisons do not sound very favourable to "business" presidents.

Among the most successful presidents of this period, regardless of party affiliation, do the historians count presidents A. Lincoln, W. Wilson, F. D. Roosevelt, D. Eisenhower, J. F. Kennedy or R. Reagan, mostly long-term career politicians. On the other hand, none of the successful businessmen who later became presidents "made it" among the ten most successful presidents of all time, and none of them was even elected a second time.

A recent example is the relatively successful oilman G. H. W. Bush, who was replaced after five years by professional politician B. Clinton, and another businessman, G. W. Bush who was replaced by a successful legal counsel B. Obama.

On the other hand, H. Truman, who failed in business and was forced to enter the state administration due to existential reasons, is counted among the relatively more successful presidents.

\subsection{Leadership and management skills comparisons}

Many of the leadership and management prerequisites, necessary for success, are undoubtedly common in business and politics. However, it should also be noted that despite all the changes in the managerial style of large corporations, including the emphasis on the leadership assumptions of their representatives, companies, in terms of their management, remain (and have to remain) essentially autocracies (with some participative features).

Their leaders can choose their co-workers and their actions are almost completely under control. The ability to listen, persuade, engage in dialogue, lead by example and reach consensus, important for political leaders, is, of course, also beneficial in business. However, its representatives almost always have at hand, and are usually accustomed to use, more directive or power tools, at with they feel more comfortable.

Therefore, many successful representatives of the corporate world do not excel in empathy, ability or effort to communicate regularly and openly with their employees, follow their interests and concerns, or openly face their questions. Many even like to remain almost invisible to their employees and, in their irreplaceable communication role, are willing to be represented, albeit not very happily, by others.

On the contrary, these assumptions are crucial for politics, including the ability to understand and reconcile different opinions and interests. Of course, we do not mean that politicians always have them. 


\subsection{The psychological traits role}

The goals of business, i.e. to make a profit, and the goals of politics or public administration, i.e. to serve citizens, are largely different. It is, therefore, only natural that, among other things, they quite often require, at least in part, different personal abilities.

In terms of personality traits, successful businessmen are necessarily pragmatic. Market pressure does not allow them anything else. If a company is not successful, they can sell or close it. However, political leaders must at least partially take care of groups or areas that are temporarily or permanently unsuccessful.

In addition, the pragmatism of businessmen often leads them to the habit not follow more permanent values or principles [19, 20]. However, political leadership usually requires certain values or principles. They give instructions on how to proceed or what principles to follow in situations that are not and cannot be clearly regulated by law. [20 22].

The same goes for visions, an important policy tool. Many companies or businessmen have adopted this tool in recent years and sometimes successfully. In most cases, however, corporate visions are very far from being able to really bring employees together, motivate them or get them to fulfil them [22 - 25]. Unfortunately, more often than not, these are just not very convincing style exercises, to which employees do not pay more attention.

\section{Results}

Practical economic experience is undoubtedly valuable. However, successful entrepreneurs or managers are sometimes susceptible to the illusion that what is good for a particular company or industry (and we do not mean only their own) is beneficial for the economy or society as a whole, and vice versa. Their beliefs may be sincere, but the fact is that this is not the case.

An example is competition, which is important for the development of the economy because it reduces costs and prices and forces innovation. However, it often reduces profits for individual companies and therefore they often try to prevent it in every possible way. Something similar applies to export promotion. It is certainly beneficial for a company to export a lot, but not everyone can export. In the longer term, the value of exports must be equal to the value of imports. In economics, unlike business, it is simply true that every intervention has its opposite. Figuratively speaking, if we extend the time at which traffic lights are green for traffic lights, it will mean for some that they will stand longer on red.

Business experience, however, can be beneficial where it is necessary to achieve greater efficiency of state institutions or make them save.

Undoubtedly, a successful business can offer a lot to the public administration in terms of efficiency. Above all, however, it is important for public institutions to adopt certain established methods of private sector management, the use of which may not be difficult at all. The problem is rather that public organizations have long resisted them under various pretexts. The introduction of these methods therefore requires, above all, broader political will or support. In other words, rather than successful businessmen, public administration requires methods that make private business successful.

An example is the design and use of performance indicators and the responsibility for achieving them. The lukewarm relationship of the public sector to performance is often related to its low responsibility for real results. Thus, not only for the scope of activities performed, resources consumed, subsidies drawn or funds "invested", but also for the real and measurable effects of these activities and resources. 
For example, how the efficiency of tax collection has increased, how the knowledge of school leavers has increased, how health care outcomes have improved, how the cost per kilometre of motorways has changed, or how the proportion of citizens or companies' applications processed by the authorities before the deadline has increased. If a policy or public institution is to produce a result, it must be evaluated and held accountable for its achievement.

Public organizations like to compare the salaries of their managers with the salaries of private managers. However, they seldom measure their results and responsibilities in a similar way.

\section{Discussions}

As already mentioned, the importance of competition for the economy is crucial. Wherever possible, it is therefore desirable to enforce competition within the public sector as well. And not only in the field of public procurement, but everywhere where institutions that offer various public services can compete with each other.

However, even in case of a public sector managed by politicians who are former businessmen, this competition is far from frequent and/or very effective. Quite on the contrary, the motivation of businessmen-turned-politicians can quite often stand against this setting.

To illustrate this tendency, let us quote some common examples. The first one concerns the possibility to establish very simple rules that prevent large companies from obtaining subsidies for small companies, based on the competition between banks. Instead of subsidies being paid to small and medium-sized enterprises by state authorities, which almost always ends up in corruption, they can be provided by banks instead, as is the case in Britain or the United States.

The state, in this case, can only guarantee the very risky loans but the banks can still compete with each other in providing these loans, which are advantageous for them. At the same time, they may be obliged to find out the real ownership structure of the companies to which they provide guaranteed loans. And if they violate this obligation, they may lose the opportunity to obtain a state guarantee for these types of loans in the future.

Similar example concerns policy toward small and medium sized businesses. The idea, common among big businessmen, that large companies are more economically important and successful, and smaller ones less "advanced" is usually flawed. On the contrary, the reality is that large companies are often too big to be efficient. Their economic position is often based more on political power, which allows them to directly or indirectly claim public money, which is more needed in other areas.

Smaller businesses are the drivers of innovation, which large companies are often more likely to resist due to fear of devaluating their investments. They also often contribute to "healthy" growth, which is not based on budget expenditures or currency devaluation, but on new technological or business solutions.

Due to what was mentioned above, entrepreneurial experience, in our opinion, can be an advantage for the public policy especially in practical municipal policy, in which selfemployed persons or smaller entrepreneurs have always played an important role in our country.

Many of the assumptions as well as personal characteristics of successful businessmen, however, do not fit well into top politics, both in terms of their management style and a certain "professional blindness" in their approach to the economy. However, many methods of successful companies can be taken over into the state administration even without their direct involvement. 


\section{References}

1. Jensen, N.M., Malesky, E.J. (2018). Incentives to Pander, How Politicians Use Corporate Welfare for Political Gain. Cambridge: Cambridge University Press.

2. Transparency International (2013, December 4). New report by Transparency International Georgia explores movement of officials between government and business and the resulting corruption risks. https://transparency.ge/en/post/report/newreport-explores-movement-officials-between-government-business

3. Soergel, A. (2019). How Historians Rate Presidents. U.S. News \& World Report.

4. Calton, C. (2018). Why Businessmen Don't Make Good Politicians. Mises Institute. https://mises.org/wire/why-businessmen-dont-make-good-politicians

5. OECD (2010). Post-Public Employment: Good Practices for Preventing Conflict of Interest. Paris: OECD Publishing.

6. Leung, J., Scott, I. (2008). Managing Integrity: The Regulation of Post Public Employment in Britain and Hong Kong. Public Organization Review, 8 (4), 365-380. https://link.springer.com/article/10.1007/s11115-008-0067-2

7. OECD (2006). Avoiding conflict of interest in post-public employment: comparative overview of prohibitions, restrictions and implementing measures in OECD countries, Expert Meeting on Managing Conflict of Interest in the Public Service. http://www.oecd.org/officialdocuments/publicdisplaydocumentpdf/?cote=GOV/PGC/E $\mathrm{TH}(2006) 3 \&$ docLanguage $=\mathrm{En}$

8. Farrell, J., Rabin, M. (1996). "Cheap Talk." Journal of Economic Perspectives, 10 (3): 103-118. https://www.aeaweb.org/articles?id=10.1257/jep.10.3.103

9. Transparency International (2010, May 31). TI Working Paper No 06/2010: Regulating the Revolving Door.

https://issuu.com/transparencyinternational/docs/2010_wp_revolvingdoor_en

10. Transparency International (2012). The Revolving Door Phenomenon in Hungary. Transparency International Hungary. Transparency International. https://transparency.hu/wp-content/uploads/2016/02/Revolving-Door-Phenomenon-InHungary.pdf

11. Transparency International (2011). Cabs for Hire? Fixing the Revolving Door between Government and Business. Transparency International.

https://www.transparency.org.uk/sites/default/files/pdf/publications/Cabs_for_HireY_F ixing_the_Revolving_Door_between_Government_and_Business.pdf

12. Transparency International (2012). Policy Paper Series Number Two - Fixing the Revolving Door between Government and Business. Transparency International UK. https://issuu.com/transparencyuk/docs/policy_paper_series_2_-_fixing_the_

13. Mayer, D.M., Ong, M., Sonenshein, S., Ashford, S.J. (2019). The money or the morals? When moral language is more effective for selling social issues. Journal of Applied Psychology, 104(8), 1058-1076.

14. Von Mises, L. (2013). The Theory of Money and Credit. New ed., New York: Skyhorse Publishing.

15. Denzin, N.K., Lincoln, Y.S. (2011). The Sage handbook of qualitative research. 4th ed., CA: Sage Publications.

16. Yin, R.K. (2014). Case Study Research and Applications: Design and methods. 5th ed., CA: Sage Publications. 
17. O'Neill, A. (2020). Historian's Ranking of U.S. presidents 2017. Statista. https://www.statista.com/statistics/1123920/us-presidents-historian-ranking/

18. Crowe, M.L., Sleep, C.E., Carter, N.T., Campbell, W.K., Miller, J.D. (2018). Selfesteem and narcissism: An item response theory analysis of curvilinearity. Personality and Individual Differences, 128, 1-20.

19. Caha, Z. (2017). Central Europe: Ethical Overlaps of Environmental and Economic Interests in Coming Years. Science and Engineering Ethics, 24(6), 1801-1907.

20. Chen, G., Hambrick, D. (2012). CEO replacement in turnaround situations: Executive (mis)fit and its performance implications. Organization Science, 23(1), 225-243.

21. Caha, Z., Vokoun, M. (2017). The Impact of the Presence of a Code of Ethics on the Economic Prosperity of a Company. In O. Dvoulety, M. Lukes \& J. Misar (Eds.) Proceedings of the $5^{\text {th }}$ International Conference Innovation Management, Entrepreneurship and Sustainability (IMES 2017) (pp. 72-80). Praha: Oeconomica Publishing House.

22. Caha, Z. (2017). Ethical Management in Companies in the Czech Republic and Ukraine - Comparison of the Presence of a Code of Ethics. SHS Web of Conferences, $39,01004$.

23. Chatterjee, A.K., Toffel, M.W. (2018). The new CEO activists. Harvard Business Review, 96(1), 78-89.

24. Agle, B., Nagarajan, N., Sonnenfeld, J., Srinivasan, D. (2006). Does CEO charisma matter? An empirical analysis of the relationships among organizational performance, environmental uncertainty, and top management team perceptions of CEO charisma. Academy of Management Journal, 49, 161-174.

25. Caha, Z. (2017). The Education and Development of Company Managers in the Czech Republic and Ukraine. SHS Web of Conferences, 39, 01003. 